\title{
Supporting Information: \\ Influence of size and cross-linking density of microgels on cellular uptake and uptake kinetics
}

\author{
Victoria K. Switacz, ${ }^{1, \S}$ Sarah K. Wypysek, ${ }^{2, \S}$ Rudolf Degen, ${ }^{1, \S}$ Jérôme J. Crassous, ${ }^{2}$ \\ Marc Spehr, ${ }^{{ }^{*}}$ Walter Richtering ${ }^{2 *}$
}

${ }^{1}$ Department of Chemosensation, Institute of Biology II, RWTH Aachen University, 52074 Aachen, Germany

${ }^{2}$ Institute of Physical Chemistry, RWTH Aachen University, 52056 Aachen, Germany

${ }^{\S}$ These authors contributed equally to this work.

*Corresponding authors.

\section{Contents}

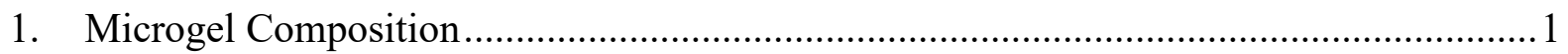

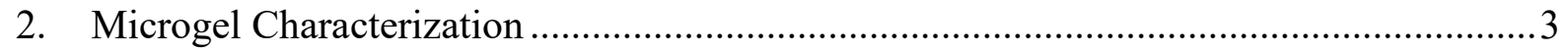

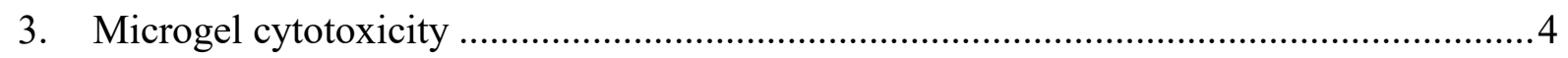

4. Confocal live-cell imaging of microgel uptake in HEK293T cells ..................................5

5. Microgel uptake kinetics and numbers of imaged cells .............................................. 8

6. Imaging of cellular fluorescence levels after removal of extracellular microgels ............9

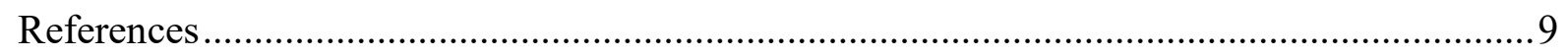




\section{Microgel Composition}

The syntheses of the microgels were based on the compositions displayed in the following tables. Table S1 gives the amounts of the chemicals used for the syntheses of the low crosslinked microgels. The composition of highly cross-linked microgels is displayed in Table S2.

Table S1. Compositions of low cross-linked microgels. This includes the weight of the main monomer NIPAM or NIPMAM; the weight and molar percentage of the co-monomer MAA, if used; the weight and molar percentage of the crosslinker BIS; the weight of the dye MRB; the weight of the surfactant SDS and the percentage of its $\mathrm{CMC}$, if used; the weight of the initiator KPS and the amount of water used for the synthesis. Additionally, temperature, stirring rate, reaction time and the procedure of purification is stated.

\begin{tabular}{|c|c|c|c|c|c|}
\hline $\begin{array}{l}\text { Labjournal- } \\
\text { code }\end{array}$ & $\begin{array}{l}\text { NIPAM-5S } \\
\text { CS70 }\end{array}$ & $\begin{array}{c}\text { NIPAM-MAA- } \\
5 \mathrm{~S} \\
\mathrm{KG}^{2} 8^{2}\end{array}$ & $\begin{array}{c}\text { NIPAM-MAA- } \\
5 \mathrm{~L} \\
\text { ST-VO-23 }\end{array}$ & $\begin{array}{l}\text { NIPAM- } \\
\text { MAA-5L* } \\
\text { JW-VO-15 }\end{array}$ & $\begin{array}{c}\text { NIPMAM-MAA- } \\
\text { 5L } \\
\text { JW-VO-17 }\end{array}$ \\
\hline NIPAM [g] & 11.0624 & 17.9908 & 4.2619 & 3.804 & \\
\hline NIPMAM [g] & & & & & 4.3800 \\
\hline $\begin{array}{l}\text { MAA }[\mathrm{g}] \\
(\mathrm{mol} \%)\end{array}$ & - & $\begin{array}{c}0.9999 \\
(6)\end{array}$ & $\begin{array}{c}0.1793 \\
(5)\end{array}$ & $\begin{array}{c}0.1153 \\
(5)\end{array}$ & $\begin{array}{l}0.1570 \\
(5)\end{array}$ \\
\hline $\begin{array}{l}\text { BIS [g] } \\
(\mathrm{mol} \%)\end{array}$ & $\begin{array}{l}0.7026 \\
\quad(5)\end{array}$ & $\begin{array}{c}1.0039 \\
(5)\end{array}$ & $\begin{array}{l}0.3292 \\
(5)\end{array}$ & $\begin{array}{l}0.275 \\
(5)\end{array}$ & $\begin{array}{c}0.276 \\
(5)\end{array}$ \\
\hline MRB [g] & 0.0114 & 0.0206 & 0.0029 & 0.0007 & 0.0007 \\
\hline $\begin{array}{l}\text { SDS }[\mathrm{g}] \\
(\% \mathrm{CMC})\end{array}$ & $\begin{array}{c}0.5095 \\
(44)\end{array}$ & $\begin{array}{c}1.8457 \\
(80)\end{array}$ & - & - & - \\
\hline KPS [g] & 0.2503 & 0.4798 & 0.0688 & 0.196 & 0.196 \\
\hline $\mathrm{H}_{2} \mathrm{O}[\mathrm{mL}]$ & 500 & 1000 & 250 & 250 & 250 \\
\hline $\mathrm{T}\left[{ }^{\circ} \mathrm{C}\right]$ & 80 & 85 & 70 & 80 & 80 \\
\hline $\begin{array}{l}\text { Stirring speed } \\
\text { [rpm] }\end{array}$ & $\begin{array}{c}\text { Yes, no } \\
\text { information on } \\
\text { speed }\end{array}$ & 350 & 200 & 250 & 250 \\
\hline Time $[\mathrm{h}]$ & 6 & 5 & 4 & 4 & 4 \\
\hline Purification & Centrifugation & $\begin{array}{l}\text { Centrifugation: } \\
5 \text { cycles; } 2 \mathrm{~h} \text {; } \\
50000 \mathrm{rpm}\end{array}$ & $\begin{array}{l}\text { Centrifugation:3 } \\
\text { cycles; } 1 \mathrm{~h} ; \\
30000 \mathrm{rpm}\end{array}$ & Dialysis & Dialysis \\
\hline
\end{tabular}


Table S2. Composition of highly cross-linked PNIPAM microgels. This includes the weight of the main monomer NIPAM; the weight and molar percentage of the co-monomer MAA; the weight and molar percentage of the crosslinker BIS; the weight of the dye MRB; the weight of the surfactant SDS and the percentage of its CMC, if used; the weight of the initiator KPS and the amount of water used for the synthesis. Additionally, temperature, stirring rate, reaction time and the procedure of purification is stated.

\begin{tabular}{|c|c|c|c|c|}
\hline $\begin{array}{l}\text { Labjournal- } \\
\text { code }\end{array}$ & $\begin{array}{c}\text { NIPAM-MAA- } \\
15 \mathrm{~S} \\
{\mathrm{KG} 11^{2}}^{2}\end{array}$ & $\begin{array}{l}\text { NIPAM-MAA- } \\
\text { 10L } \\
\text { ST-VO-22 }\end{array}$ & $\begin{array}{l}\text { NIPAM-MAA- } \\
\text { 13L } \\
\text { ST-VO-16 }\end{array}$ & $\begin{array}{c}\text { NIPAM-MAA- } \\
\text { 15L } \\
\text { ST-VO-26 }\end{array}$ \\
\hline NIPAM [g] & $\begin{array}{l}0.9617 \text { (I) } \\
1.4401 \text { (II) }\end{array}$ & 3.3454 & 3.802 & $\begin{array}{l}1.2686 \text { (I) } \\
1.9009 \text { (II) }\end{array}$ \\
\hline $\begin{array}{l}\text { MAA }[\mathrm{g}] \\
(\mathrm{mol} \%)\end{array}$ & $\begin{array}{c}0.0621 \text { (I) } \\
0.0935 \text { (II) } \\
(8)\end{array}$ & $\begin{array}{c}0.1506 \\
(5)\end{array}$ & $\begin{array}{c}0.1540 \\
(4)\end{array}$ & $\begin{array}{c}0.0602 \text { (I) } \\
0.0904 \text { (II) } \\
(5)\end{array}$ \\
\hline BIS [g] & $\begin{array}{c}0.0900(\mathrm{I}) \\
0.3607 \text { (II) } \\
(15)\end{array}$ & $\begin{array}{c}0.5321 \\
(10)\end{array}$ & $\begin{array}{c}0.8170 \\
(13)\end{array}$ & $\begin{array}{c}0.1616(\mathrm{I}) \\
0.6500(\mathrm{II}) \\
(15)\end{array}$ \\
\hline $\begin{array}{l}\mathrm{MRB}[\mathrm{g}] \\
\mathrm{SDS}[\mathrm{g}] \\
(\% \mathrm{CMC})\end{array}$ & $\begin{array}{c}0.0016 \\
0.1070 \\
(30)\end{array}$ & 0.0023 & 0.0007 & 0.0023 \\
\hline KPS $[\mathrm{g}]$ & 0.0711 & 0.1352 & 0.1940 & 0.0675 \\
\hline $\mathrm{H}_{2} \mathrm{O}[\mathrm{mL}]$ & $\begin{array}{l}130 \text { (I) } \\
20 \text { (II) }\end{array}$ & 250 & 250 & $\begin{array}{l}200 \text { (I) } \\
50 \text { (II) }\end{array}$ \\
\hline $\mathrm{T}\left[{ }^{\circ} \mathrm{C}\right]$ & 80 & 85 & 80 & 70 \\
\hline $\begin{array}{l}\text { Stirring speed } \\
{[\mathrm{rpm}]}\end{array}$ & 300 & 350 & 280 & 200 \\
\hline Time $[\mathrm{h}]$ & 5 & 4 & 4 & 4 \\
\hline Purification & $\begin{array}{l}\text { Centrifugation: } \\
4 \text { cycles; } 1 \mathrm{~h} \text {; } \\
50000 \mathrm{rpm}\end{array}$ & $\begin{array}{l}\text { Centrifugation: } \\
3 \text { cycles; } 1 \mathrm{~h} ; \\
30000 \mathrm{rpm}\end{array}$ & $\begin{array}{l}\text { Centrifugation: } \\
3 \text { cycles; } 1 \mathrm{~h} ; \\
30000 \mathrm{rpm}\end{array}$ & $\begin{array}{l}\text { Centrifugation: } \\
3 \text { cycles; } 1 \mathrm{~h} ; \\
30000 \mathrm{rpm}\end{array}$ \\
\hline
\end{tabular}




\section{Microgel Characterization}

For investigating the size of the microgels, their hydrodynamic radius $\left(\mathrm{D}_{\mathrm{h}}\right)$ was determined via DLS. Calculation of the swelling ratio $\alpha$ was done via division of $\mathrm{D}_{\mathrm{h}}\left(\mathrm{ECS}, 20^{\circ} \mathrm{C}\right)$ by $\mathrm{D}_{\mathrm{h}}(\operatorname{most}$ collapsed state) for $\alpha(\mathrm{ESC})$, and of $\mathrm{D}_{\mathrm{h}}$ (most swollen state) by $\mathrm{D}_{\mathrm{h}}$ (most collapsed state) for $\alpha_{\max }$. The required $\mathrm{D}_{\mathrm{h}}$ in the most swollen and collapsed state of the microgels are listed in Table S3.

Table S3. Overview of the $\mathrm{Dh}_{\mathrm{h}}$ of the microgels in their most swollen and their most collapsed state. The listed $\mathrm{D}_{\mathrm{h}}$ are used to calculate the respective swelling ratios of the microgels.

\begin{tabular}{lcc}
\hline Sample code & $D_{\mathrm{h} \text { (most swollen) [nm] }}$ & $D_{\mathrm{h} \text { (most collapsed) [nm] }}$ \\
\hline NIPAM-5S & $204 \pm 9$ & $112 \pm 6$ \\
NIPAM-MAA-5S & $202 \pm 1$ & $76 \pm 1$ \\
NIPAM-MAA-15S & $330 \pm 5$ & $142 \pm 1$ \\
NIPAM-MAA-5L & $993 \pm 11$ & $390 \pm 2$ \\
NIPAM-MAA-5L* & $956 \pm 20$ & $453 \pm 3$ \\
NIPAM-MAA-10L & $1102 \pm 14$ & $583 \pm 4$ \\
NIPAM-MAA-13L & $1125 \pm 14$ & $583 \pm 4$ \\
NIPAM-MAA-15L & $973 \pm 12$ & $633 \pm 5$ \\
NIPMAM-MAA-5L & $1278 \pm 27$ & $633 \pm 9$ \\
\hline
\end{tabular}




\section{Microgel cytotoxicity}

To ensure cell viability after exposure to microgels, we tested microgels of various architectures for potential cytotoxicity using standard live-dead assays. Figure S1 shows that exposure to microgels did not cause significant cell death within an incubation period of $36 \mathrm{~h}$.

n.s.

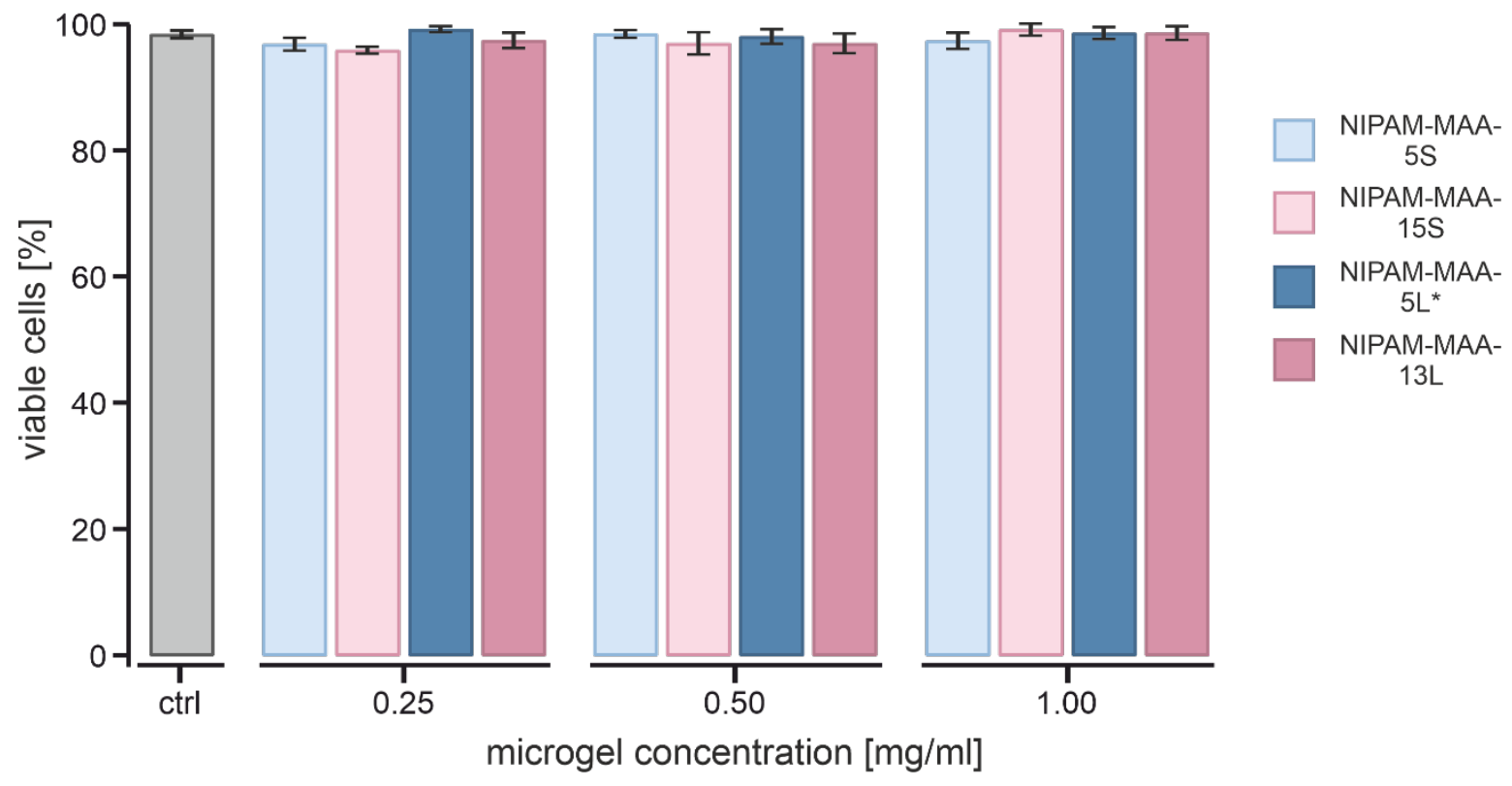

Figure S1. PNIPAM-based microgels do not affect cell viability and proliferation over $36 \mathrm{~h}$. HEK293T cells were incubated for $36 \mathrm{~h}$ with microgels at three different concentrations $(0.25 \mathrm{mg} / \mathrm{mL}, 0.5 \mathrm{mg} / \mathrm{mL}, 1 \mathrm{mg} / \mathrm{mL})$ at $37{ }^{\circ} \mathrm{C}$. Cells cultivated for $36 \mathrm{~h}$ without microgels at the same cell density were used as control ("ctrl"). Afterwards, a live-dead staining of the cells was performed using FDA and DAPI. Number of DAPI-stained cells was calculated and used for estimation of cell viability. n.s. indicates no statistical differences (ANOVA). 


\section{Confocal live-cell imaging of microgel uptake in HEK293T cells}

The interactions of microgels with cells was investigated using live-cell confocal microscopy. Correspondingly, Figure S2 depicts confocal live-cell images of HEK293T cells exposed to small PNIPAM microgels. In Figure S3, interactions of HEK293T cells with large PNIPMAM and large PNIPAM microgels are shown, while Figure S4 shows respective images of large PNIPAM microgels.
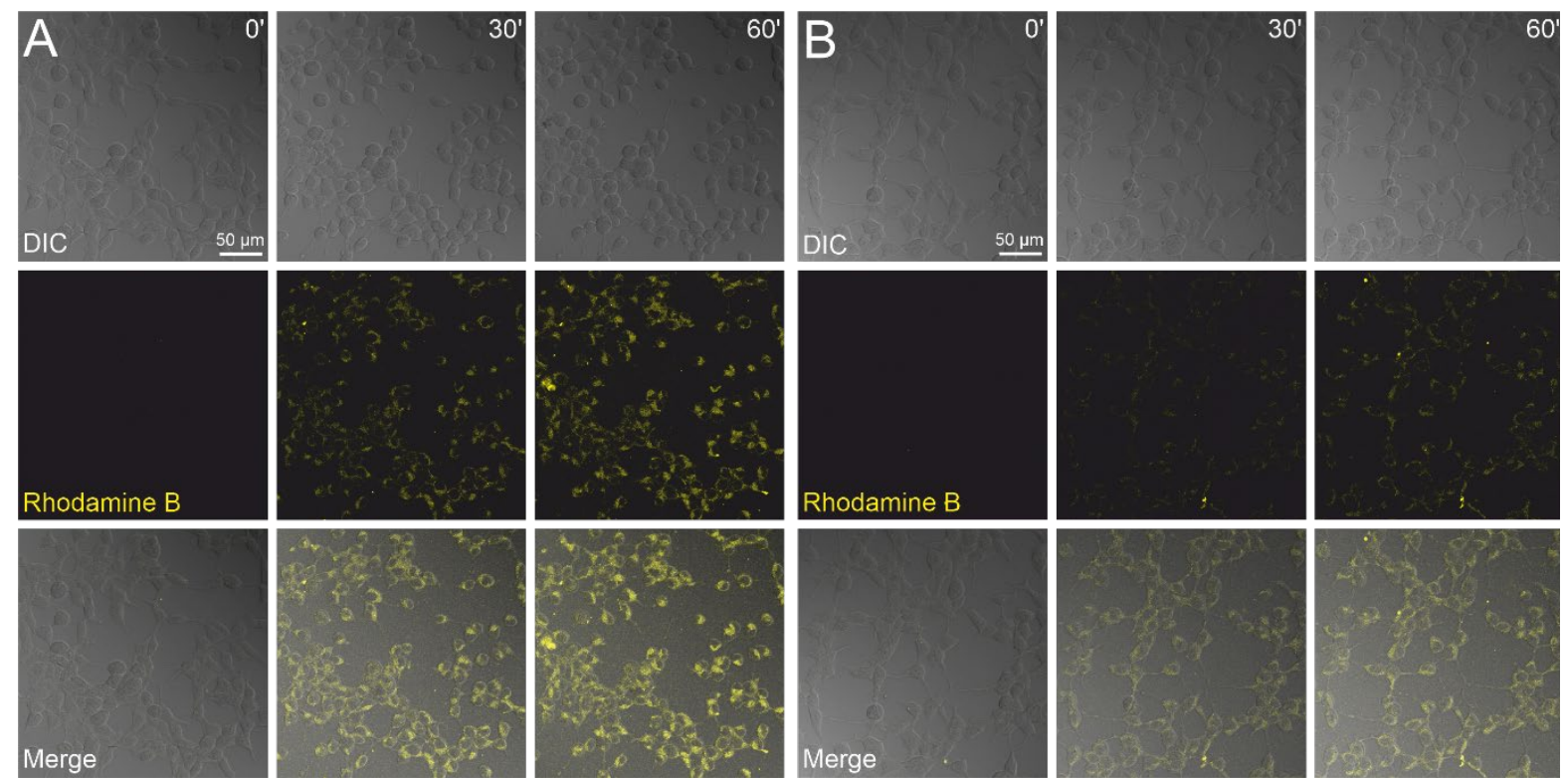

Figure S2. Confocal live-cell imaging of microgel uptake in HEK293T cells using small PNIPAM microgels. Overview images showing HEK293T cells using differential interference contrast microscopy ("DIC") and confocal live-cell imaging ("Rhodamine B") before ( $1^{\text {st }}$ column), 30 min after ( $2^{\text {nd }}$ column) and 60 min after $\left(3^{\text {rd }}\right.$ column $)$ exposure to fluorescently labeled PNIPAM microgels. The last row depicts the colocalization of cells and microgels ("Merge"). (A) HEK293T cells exposed to the microgel NIPAM-5S. (B) Exposure of HEK293T cells to NIPAM-MAA-15S microgels. 


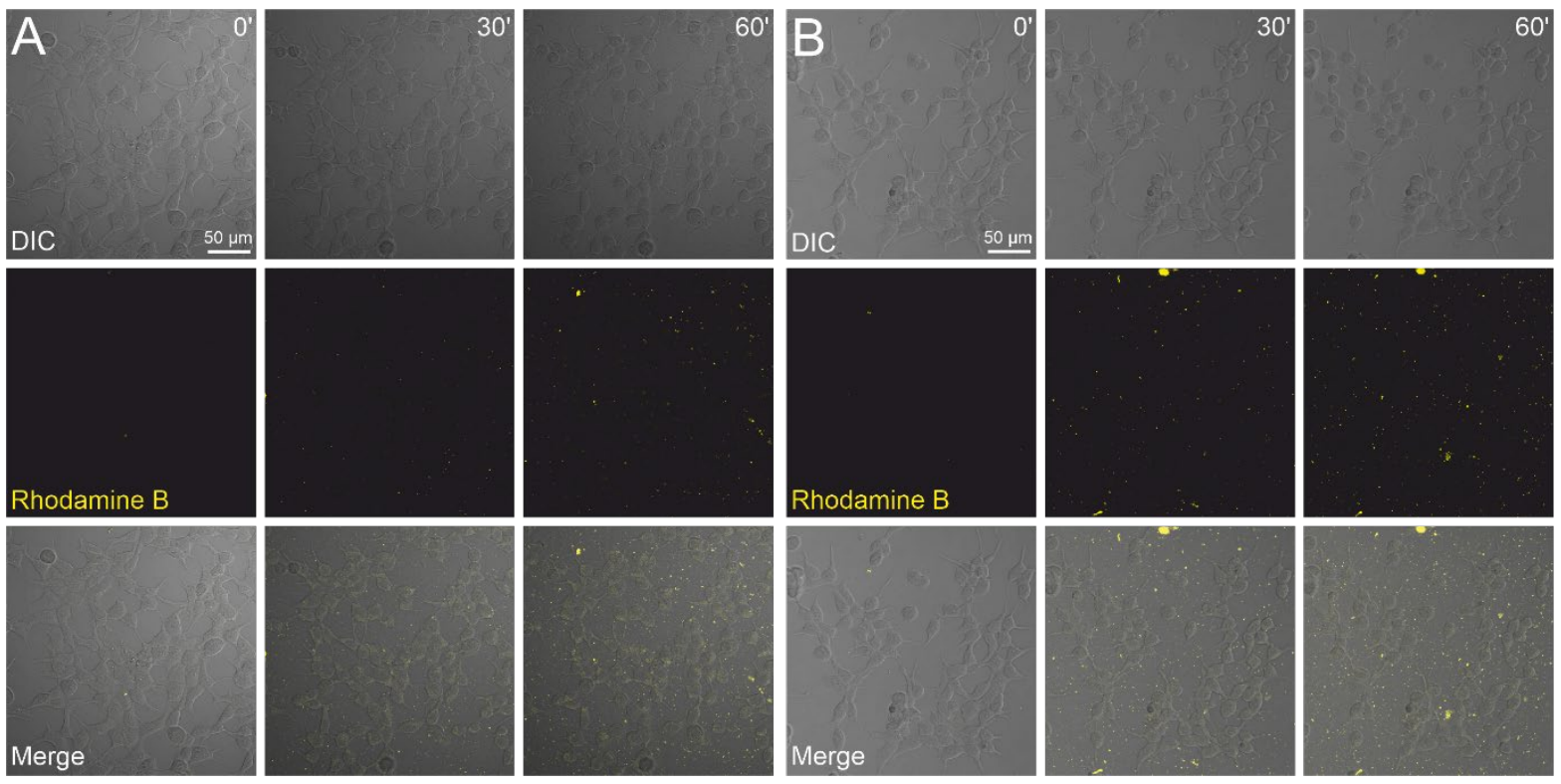

Figure S3. Confocal live-cell imaging of microgel uptake in HEK293T cells using large PNIPMAM and PNIPAM microgels. Overview images showing HEK293T cells using differential interference contrast microscopy ("DIC") and confocal live-cell imaging ("Rhodamine B") before ( ${ }^{\text {st }}$ column), 30 min after $\left(2^{\text {nd }}\right.$ column $)$, and $60 \mathrm{~min}$ after ( $3^{\text {rd }}$ column) exposure to fluorescently labeled PNIPMAM microgels. The last row depicts the colocalization of cells and microgels ("Merge"). (A) HEK293T cells exposed to the microgel NIPMAM-MAA-5L. (B) Exposure of HEK293T cells to NIPAM-MAA-5L" microgels. 


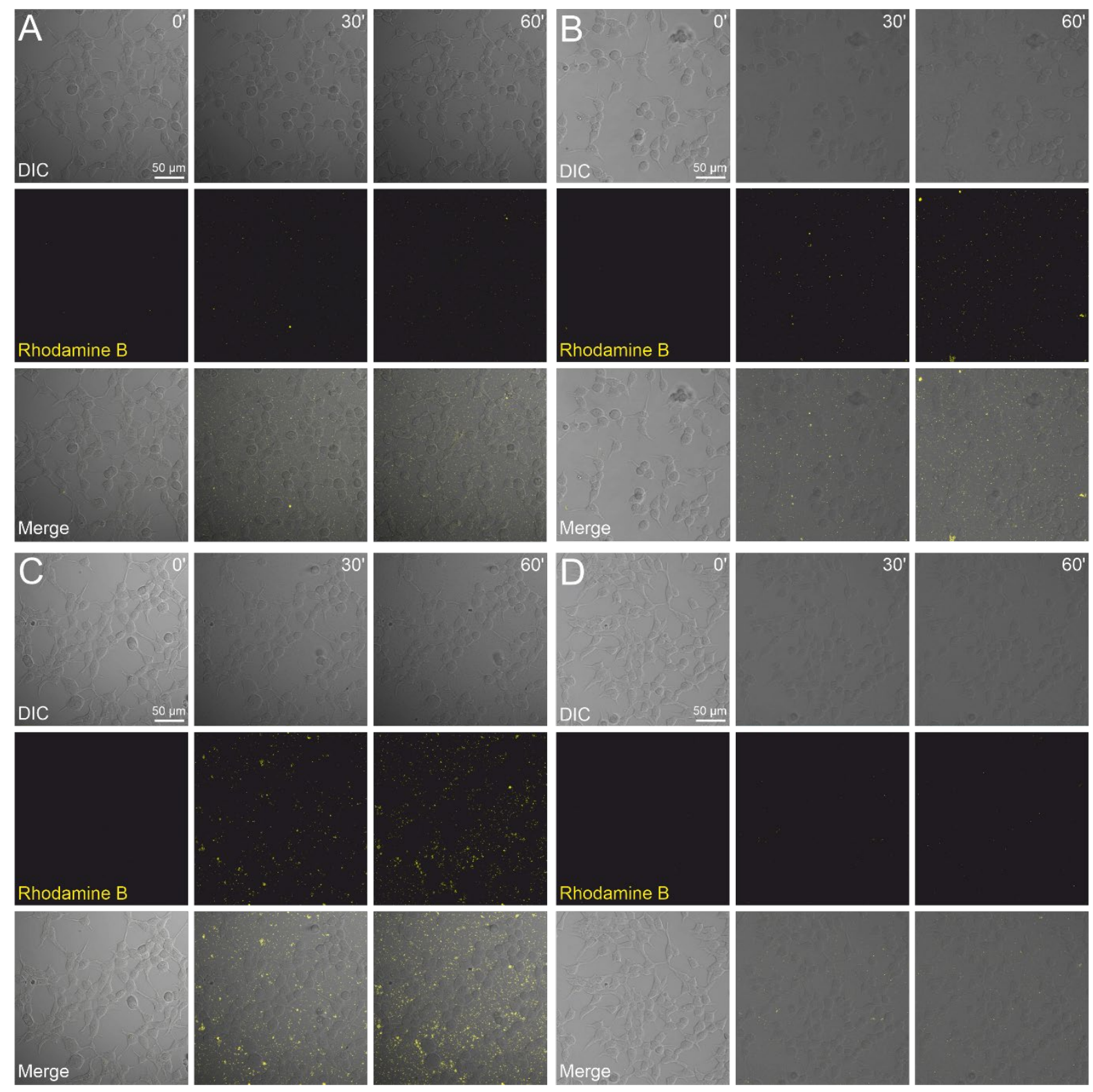

Figure S4. Confocal live-cell imaging of microgel uptake in HEK293-T cells using large PNIPAM microgels. Overview images showing HEK293T cells using differential interference contrast microscopy ("DIC") and confocal live-cell imaging ("Rhodamine B") before ( $1^{\text {st }}$ column), 30 min after $\left(2^{\text {nd }}\right.$ column $)$ and 60 min after $\left(3^{\text {rd }}\right.$ column $)$ exposure to fluorescently labeled PNIPAM microgels. The last row depicts the colocalization of cells and microgels ("Merge"). (A) HEK293T cells exposed to the microgel NIPAM-MAA-5L. (B) Exposure of HEK293T cells to NIPAM-MAA-10L microgels. (C) HEK293T cells exposed to the microgel NIPAM-MAA-13L. (D) Exposure of HEK293T cells to NIPAMMAA-15L microgels. 


\section{Microgel uptake kinetics and numbers of imaged cells}

Table S4. Overview of calculated microgel uptake kinetics using the time constant $\tau$.

\begin{tabular}{|c|c|c|c|c|c|c|c|c|c|}
\hline \multirow{3}{*}{$\begin{array}{l}\text { Sample code } \\
\text { NIPAM-5S }\end{array}$} & \multirow{3}{*}{$\begin{array}{c}\begin{array}{c}\mathrm{n} \\
\text { all cells }\end{array} \\
464\end{array}$} & \multirow{2}{*}{\multicolumn{2}{|c|}{$\begin{array}{c}\mathrm{n} \text { analysed } \\
\text { cells } \\
\text { (percentage) }\end{array}$}} & \multicolumn{6}{|c|}{$\tau[\mathrm{s}]$} \\
\hline & & & & \multirow{2}{*}{$\begin{array}{l}\text { mean } \\
1284\end{array}$} & \multirow{2}{*}{$\begin{array}{r}\text { SD } \\
838\end{array}$} & \multirow{2}{*}{$\begin{array}{c}\text { SEM } \\
43\end{array}$} & \multirow{2}{*}{$\begin{array}{r}\text { median } \\
1100\end{array}$} & \multirow{2}{*}{$\begin{array}{c}\begin{array}{c}\text { lower } \\
\text { quartile }\end{array} \\
672\end{array}$} & \multirow{2}{*}{$\begin{array}{c}\begin{array}{r}\text { upper } \\
\text { quartile }\end{array} \\
1639\end{array}$} \\
\hline & & 386 & $(83.2 \%)$ & & & & & & \\
\hline NIPAM-MAA-5S & 538 & 483 & $(89.8 \%)$ & 973 & 807 & 37 & 732 & 459 & 1207 \\
\hline NIPAM-MAA-15S & 500 & 308 & $(63.6 \%)$ & 1351 & 1019 & 58 & 1089 & 537 & 1854 \\
\hline NIPAM-MAA-5L & 557 & 442 & $(79.4 \%)$ & 1833 & 1085 & 52 & 1610 & 956 & 2500 \\
\hline NIPAM-MAA-5L* & 557 & 338 & $(60.1 \%)$ & 1831 & 1188 & 65 & 1544 & 862 & 2630 \\
\hline NIPMAM-MAA-5L & 474 & 309 & $(61.8 \%)$ & 1938 & 1253 & 71 & 1749 & 921 & 2889 \\
\hline
\end{tabular}




\section{Imaging of cellular fluorescence levels after removal of extracellular microgels}

To investigate whether microgels undergo cellular extrusion (and/or degradation) after internalization, we performed washout experiments. Here, we incubated HEK293T cells with microgels for $1 \mathrm{~h}$ and, subsequently, we removed extracellular microgels by exchanging the bath ECS devoid of microgels. Cellular fluorescence intensities were then measured for up to $36 \mathrm{~h}$ after microgel removal. Within $1 \mathrm{~h}$ after the washout, we observed a massive decline in fluorescence, indicating that extrusion / degradation mechanisms exist that likely balance ongoing uptake under conditions of continuous extracellular microgel presence.

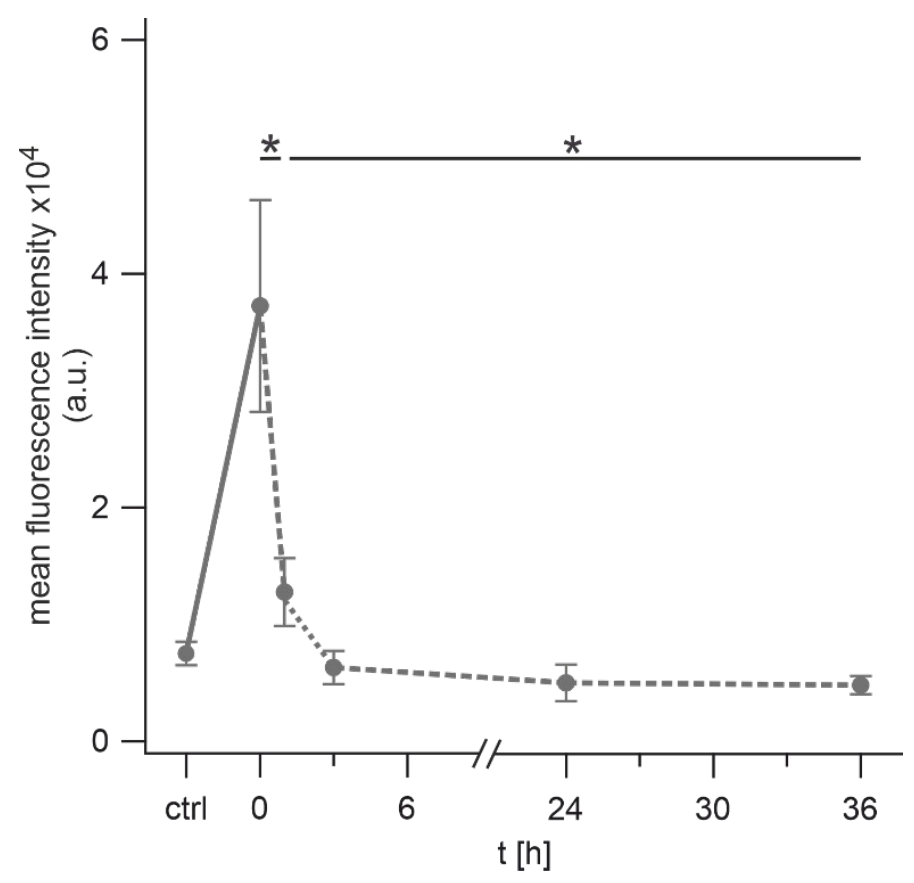

Figure S5. Washout experiment. Cells were incubated with microgel NIPAM-MAA-5S (c $=0.5 \mathrm{mg} / \mathrm{mL})$ for $1 \mathrm{~h}$. Subsequently, extracellular microgels were removed by ECS exchange. Then, cells were incubated at $37^{\circ} \mathrm{C}$ in absence of microgels and fluorescence intensity was measured after 1, 3, 24, or $36 \mathrm{~h}$. Data is displayed as means $\pm \mathrm{SD}$. Microgel exposure $(1 \mathrm{~h}$; ctrl $-\mathrm{t}$ ) triggers a robust increase in cell-specific fluorescence intensity (solid line). Removal of extracellular microgels reveals a significant decrease of cellular fluorescence intensity (dashed line), which reaches control levels within $3 \mathrm{~h}$ and remains low for at least an additional $36 \mathrm{~h}$ (one-way ANOVA, $p \leq 0.05$ ).

\section{References}

(1) Scherzinger, C. Cononsolvency of Microgels: Phase Behaviour, Structure and Dynamics. Dissertation, RWTH Aachen University, Aachen, 2014.

(2) Geisel, K. Microgels at Oil-Water Interfaces: Deformation, Assembly and Compression. Dissertation, RWTH Aachen University, Aachen, 2015. 